\title{
Two Techniques of Intestinal Wall Suture in Surgical Treatment of Ileus in Dogs and the Importance of Omentalisation
}

\author{
M. CRHA, J. LORENZOVÁ, L. URBANOVÁ, T. FICHTEL, A. NEČAS \\ Department of Surgery and Orthopaedics, Small Animal Clinic, Faculty of Veterinary Medicine, \\ University of Veterinary and Pharmaceutical Sciences Brno, Czech Republic
}

Received November 12, 2007

Accepted February 14, 2008

\begin{abstract}
Crha M., J. Lorenzová, L. Urbanová, T. Fichtel, A. Nečas: Two Techniques of Intestinal Wall Suture in Surgical Treatment of Ileus in Dogs and the Importance of Omentalisation. Acta Vet. Brno 2008, 77: 263-267.

Model experimental studies focused on the intestinal suture techniques in relation to healing, postoperative narrowing of the intestinal lumen or adhesion formation can not comprise a number of clinical factors (foreign body presence in the intestine, haematological abnormalities, septic peritonitis, different age of patients, etc.) that under clinical practice conditions may have an effect on the healing of the intestinal suture. The aim of this clinical study was to confirm in a group of dogs surgically treated for small bowel obstruction, whether different techniques of its wall suture may affect the frequency of possible dehiscence occurrence.

This study compares two different techniques of intestinal wall suture in relation to postoperative dehiscence of the intestinal wall closure. Based on the clinical observation with regard to the risk of postoperative dehiscence and possible complications in form of adhesions, also the importance of omentalisation in the suture of small bowel was evaluated.

No significant difference was demonstrated $(p>0.05)$ in the frequency of postoperative dehiscence at the site of the intestinal wall closure between the two-layer inverting and singlelayer appositional techniques of suture. Likewise, no significant difference was demonstrated $(p>0.05)$ in the frequency of dehiscence of intestinal wall suture between patients that underwent intestinal suture omentalisation and those whose intestinal wall suture was not complemented with omentalisation.

Based on the results of this clinical study it may be stated that both manual single-layer approximation technique and two-layer inverting technique of the intestinal wall suture are equally safe from the viewpoint of possible dehiscence, and it depends on the surgeon's preference, which one of the said techniques he or she chooses. Concurrently it may be assumed that an exactly performed suture of the intestinal wall does not necessarily require omentalisation.
\end{abstract}

Intestine, obstruction, dehiscence

Several experimental studies may be found in literature, dealing with individual techniques of intestinal suture in relation to healing, postoperative narrowing of the intestinal lumen or adhesion formation (Bennett and Zydeck 1970; Ellison et al. 1982; Bone et al. 1983). For this purpose, mainly approximation, inverting, or everting sutures were studied. These studies were done under experimental conditions, which exclude the effects of a number of clinical factors (e.g. presence of a foreign body in the bowel, haematological abnormalities, septic peritonitis, different age of patients, etc.) on the healing of the intestinal wall closure. We therefore decided to determine under conditions of clinical practice, whether different techniques of the intestinal wall suture may affect the frequency of occurrence of intestinal anastomotic dehiscence. Omentalisation and "serous patch" are surgical techniques that aim to form a permanent adhesion, either between the omentum and the intestine in the case of omentalisation; or in the case of the "serous patch", between two serous surfaces of neighbouring bowel loops (Hedlund 2002; Brown 2003). The purpose of these techniques is to decrease the risk of dehiscence and leakage of the bowel content in the

Address for correspondence:

MVDr. Michal Crha, Ph.D.

Department of Surgery and Orthopaedics

Small Animal Clinic

Faculty of Veterinary Medicine

University of Veterinary and Pharmaceutical Sciences Brno

Palackeho 1-3, 61242 Brno, Czech Republic

Phone: +420 541562362

E-mail: crham@vfu.cz

http://www.vfu.cz/acta-vet/actavet.htm 
intestinal wall suture in cases with uncertain prognosis. The serous patch may be also used for the purpose of decreasing the number of recurrences of intussusception (Brown 2003). Omentalisation positively influences intestinal healing, as the omentum provides blood supply and lymphatic drainage, and by formation of fibrinous adhesions to the surgical incision it prevents the leakage of the bowel content from the intestinal lumen into the abdominal cavity (McLachlin and Denton 1973; Ellison 1989). The omentum also plays an important immune and haemostatic role, and due to its characteristics it is likened to "abdominal police". Apart from abdominal surgery, the omentum has a wide use also in thoracic, urogenital, or vascular surgery and techniques of its use are even described for the treatment of poorly healing skin wounds (Smith et al. 1995; Bray et al. 1997; Birchard et al. 1998). For the purpose of the protective function of the omentum in the intestinal wall healing, some authors recommend omentalisation of the suture immediately after performing intestinal anastomosis (Hedlund 2002; Kirby 2003).

The aim of this clinical study was to

1) compare the results of surgical treatment while using the manually sutured singlelayer approximation technique and the two-layer inverting technique in the intestinal wall suture in dogs (enterotomy and enterectomy),

2) determine the clinical importance of omentalisation in surgical interventions in the small intestine in dogs with regard to the occurrence of postoperative complications in form of the leakage of the bowel content into the abdominal cavity or the occurrence of complications resulting from the adhesions of serous organs in the abdominal cavity.

\section{Materials and Methods}

The clinical study included 52 patients treated for small bowel ileus, of a total number of 10,776 patients treated at the Department of Surgery and Orthopaedics of the Small Animal Clinic at the University of Veterinary and Pharmaceutical Sciences Brno in the period from January 2003 to December 2005. All patients underwent preoperative clinical examination, haematological and biochemical examination of blood samples, as well as radiological and ultrasonographic examination of the abdominal cavity organs. In the framework of surgical treatment, the type of the suture used was recorded, and whether it was, or conversely, was not omentalised (Plate IV, Fig. 1). The intestinal suture was hand-sewn, by single-layer appositional technique using individual Gambee sutures (Plate IV, Fig. 2), or by two-layer inverting technique (simple continuing suture on the mucosa and submucosa in the first layer; Cushing suture on the seromuscular layer of the intestine in the second layer). In all cases of anastomosis, monofilament suture material polyglecapron 25 (Monocryl) was used. We also compared frequencies of dehiscence of the surgical wound of the intestine in relation to the intestinal wall suture techniques used, without regard to the surgical intervention performed (enterotomy or enterectomy). The patient was clinically monitored during hospitalisation, and then on days 10 to 14 after surgery during a follow-up connected with the extraction of skin sutures from the laparotomy incision. Monitoring of postoperative complications focused on the occurrence of apathy, loss of appetite, diarrhoea, vomiting and the occurrence of postoperative peritonitis resulting from the leakage of the bowel content into the peritoneal cavity. Long-term postoperative monitoring of these patients focused on weight loss, signs of pain in the abdominal cavity, vomiting or diarrhoea. Results were recorded on the basis of clinical examination or a phone consultation with the owner, minimally 6 months after the surgical intervention.

For statistical evaluation of the qualitative indicators in groups of patients $\chi^{2}$-test was used; for comparison of files of a small number of data Fisher's exact test was used (Göpfertová et al. 1999). All data were statistically evaluated and mutually compared using the programme Microsoft Excel 2002, SPSS 11.0.0., or SISA(Göpfertová et al. 1999).

\section{Results}

Of the total number of all 10,776 patients treated at the Department of Surgery and Orthopaedics of the Small Animal Clinic during 3 years (2003 to 2005), patients with small bowel obstruction represented $0.48 \%$.

In 28 patients hand-sewn single-layer approximation suture of the intestinal wall was performed, whereas in the remaining 24 patients two-layer inverting technique of the intestinal wall suture was performed. Postoperative dehiscence of the intestinal suture occurred in two cases of suture using the approximation technique, and in one case of 
suture using the inverting technique. No significant difference was demonstrated $(p>0.05)$ in the frequencies of postoperative dehiscence of the intestinal wall suture between groups of patients treated with these different techniques of intestinal wall suture. Omentalisation was performed in 36 patients; contrarily, it was not performed in 16 patients. Postoperative dehiscence of the intestinal suture occurred in two patients in the case of performed omentalisation, and in one patient without performed omentalisation (Plate V, Fig. 3). No significant difference was found $(p>0.05)$ in the frequencies of postoperative dehiscence of the intestinal wall suture between the group of patients with performed omentalisation and the group of patients without performed omentalisation.

\section{Discussion}

Hand-sewn techniques of intestinal anastomosis are the most widely spread, and routinely used in practice. Approximation techniques of intestinal anastomosis are recommended in dogs for reasons of a lower risk of the intestinal chyme leakage from the intestinal lumen, faster healing and minimal enteric stenosis (Ellison et al. 1982; Brown 2003). An alternative to this suture technique is two-layer inverting anastomosis, traditionally used in humans. It involves the external layer, forming a seroserous contact, and the internal haemostatic layer (Irvin and Goligher 1973; O' Kelly and Krukowski 1998). The disadvantage of this suture technique is a more marked narrowing of the intestinal lumen. Some experimental studies mention also more pronounced tissue injury leading to longer surgical wound healing (Bennett and Zydeck 1970; Richardson 1981; Ellison 1981). In the framework of our study, no difference was demonstrated in the use of the two techniques in the suture of small intestinal wall in dogs in relation to the occurrence of postoperative mortality or morbidity caused by dehiscence or eventual narrowing of the intestinal lumen. Our assertion is, however, based on the clinical monitoring of patients and does not challenge the results of previous experimental studies that evaluated histologically the intestinal healing process in dogs after their euthanasia.

The clinical importance of omentalisation observed within our group of patients did not confirm its fundamental influence on development of complications accompanied by increased postoperative morbidity due to adhesions or the leakage of the intestinal content caused by dehiscence of the intestinal wall suture. No significant difference was found $(p<0.05)$ between mortality of patients whose intestinal suture was overlaid with the omentum during surgery and that of patients without omentalisation. This fact may be explained by the thorough check of the suture tightness during surgery, when the protective role of the omentum could not manifest itself significantly; or conversely, spontaneous adhesion of the omentum to the site of suture occurred in spite of the fact that it was not intentionally fixed on the operated part of the intestine. This latter explanation is supported by findings of experimental studies in dogs, confirming that almost always following a surgical intervention in the intestine, adhesion of the omentum at the site of the intestinal wall suture was demonstrated (Ellison et al. 1982; Bone et al. 1983; Coolman et al. 2000). The omentum positively affects intestinal wall healing, as it provides sufficient blood supply, lymphatic drainage, and by formation of fibrinous adhesions it prevents the leakage of the bowel content into the abdominal cavity (McLachlin and Denton 1973; Ellison 1989). The protective role of the omentum in the abdominal cavity can not be denied; therefore, we incline toward the opinions (Hedlund 2002; Brown 2003) recommending suture omentalisation immediately after performing intestinal anastomosis for the purpose of its protection from the leakage of intestinal chyme.

In comparison to dogs, adhesions as complications of surgical interventions in the abdominal cavity occur much more frequently in horses and humans (Monk et al. 1994; Semevolos et al. 2002; Mair and Smith 2005; Plánka et al. 2006). Therefore, adhesions 
in the abdominal cavity formed in result of previous abdominal surgeries only rarely participate in the small bowel obstruction in dogs (Ellison 1989). Menzies and Ellis (1990) mention in their clinical study the incidence of postoperative adhesions in humans to be as high as $93 \%$, however, objective clinical complaints caused by these adhesions are manifested in a relatively small percentage of patients. Within the scope of our study, we monitored 52 patients operated on for small bowel obstruction; after more than six months from surgery, none of them showed clinical signs giving evidence of adhesion formation in the abdominal cavity, requiring a repeated surgical intervention. Small bowel obstruction did not recur in any of the patients of the monitored group, whether it is due to postoperative adhesion formation in the abdominal cavity, or to stricture formation at the site of intestinal wall suture. The fact that abdominal cavity adhesions do not cause so frequent complications of previous laparotomy in dogs may be due to the higher fibrinolytic activity in the peritoneal cavity in dogs. On the other hand, it is presumable that in dogs, similarly to humans, postoperative adhesions may form relatively often, without manifesting themselves as clinical complaints. The question remains, as to how often adhesions are formed in the abdominal cavity after laparotomy surgery; to our knowledge, an objective study on this subject in dogs has not yet been published. From this viewpoint, it is advisable for the future to use the so called "second-look" laparoscopy to evaluate these findings.

In conclusion, no significant difference was demonstrated $(p<0.05)$ in the frequencies of postoperative dehiscence of the intestinal wall suture between groups of patients treated with the hand-sewn single-layer approximation technique and the two-layer inverting technique of intestinal wall suture. Therefore, it only depends on the surgeon's preference which one of the above mentioned suture techniques he or she chooses. Intestinal wall suture omentalisation did not significantly participate $(p<0.05)$ in decreasing the frequency of postoperative dehiscence of the intestinal wall suture. It may therefore be assumed that exactly performed intestinal wall suture does not necessarily require omentalisation. On the basis of postoperative monitoring of the patients in our group, no case was demonstrated in which the performed omentalisation caused postoperative complications, requiring repeated surgical intervention. Although the positive effect of omentalisation on decreasing the frequency of postoperative dehiscence of the intestinal wall suture has not been clinically confirmed, we do not challenge the results of experimental studies, confirming the positive effect of the omentum on intestinal wall healing. In this respect, intestinal wall suture omentalisation may be considered as a technique of choice that may be substantiated in practice mainly in intestinal anastomoses.

\section{Výsledky chirurgické léčby ileu u psů při použití dvou technik sutury stěny střeva a zhodnocení významu omentalizace}

Modelové experimentální práce zaměřené na techniky sutury střeva ve vztahu k hojení, pooperačnímu zúžení střevního lumen či tvorbě adhezí nemohou postihnout řadu klinických faktorů (př́itomnost cizího tělesa ve střevě, hematologické abnormality, septickou peritonitidu, rozdílné stáří pacientů apod.), které mohou mít v podmínkách klinické praxe vliv na hojení sutury střeva. Cílem této klinické studie proto bylo ověřit v souboru chirurgicky léčených psů s obstrukcí tenkého střeva, zda odlišný způsob sutury jeho stěny může ovlivnit četnost výskytu př́padné dehiscence.

V práci jsou porovnány dva odlišné způsoby sutury střevní stěny ve vztahu k pooperační dehiscenci uzávěru stěny střeva. Na základě klinického sledování je s ohledem na riziko pooperační dehiscence a na možnou komplikaci v podobě srůstů rovněž hodnocen význam omentalizace při sutuře tenkého střeva.

Nebyl prokázán statisticky významný rozdíl $(p>0,05)$ v četnostech pooperační 
dehiscence $\mathrm{v}$ místě uzávěru stěny střeva mezi invertující dvouvrstvou a apoziční jednovrstvou technikou sutury. Rovněž nebyl prokázán významný rozdíl $(p>0,05)$ v četnostech dehiscence sutury stěny střeva mezi pacienty, u nichž byla provedena omentalizace střevní sutury, a mezi pacienty, u nichž sutura stěny střeva nebyla doplněna omentalizací.

Na základě výsledků této klinické studie lze konstatovat, že jak manuální jednovrstvá aproximační technika, tak dvouvrstvá invertující technika sutury stěny střeva jsou z hlediska možné dehiscence stejně bezpečné a záleží na preferenci chirurga, kterou z uvedených technik zvolí. Lze současně předpokládat, že exaktně provedená sutura stěny střeva nutně nevyžaduje omentalizaci.

\section{References}

BENNETT RR, ZYDECK FA 1970: A comparison of single layer suture patterns for intestinal anastomosis. J Am Vet Med Assoc 157: 2075-2080

BIRCHARD SJ, SMEAK DD, McLOUGHLIN MA 1998: Treatment of idiopathic chylothorax in dogs and cats. J Am Vet Med Assoc 212: 652-657

BONE DL, DUCKETT KE, PATTON CS, KRAHWINKEL DJ 1983: Evaluation of anastomoses of small intestine in dogs: crushing versus noncrushing suturing techniques. Am J Vet Res 44: 2043-2048

BRAY JP, WHITE RA, WILLIAMS JM 1997: Partial resection and omentalization: a new technique for management of prostatic retention cysts in dogs. Vet Surg 26: 202-209

BROWN DC 2003: Small intestine. In: SLATTER DH (Ed.): Textbook of small animal surgery. $3^{\text {rd }}$ ed. Saunders, Philadelphia, pp. 660-661

COOLMAN BR, EHRHART N, PIJANOWSKI G, EHRHART EJ, COOLMAN SL 2000: Comparison of skin staples with sutures for anastomosis of the small intestine in dogs. Vet Surg 29: 293-302

ELLISON GW 1981: End-to-end anastomosis in the dog: Comparison of techniques. Compend Contin Educ Pract Vet 3: 486-495

ELLISON GW, JOKINEN MP, PARK RD 1982: End-to-end approximating intestinal anastomosis in the dog: A comparative fluorescein dye, angiographic and histopathologic evaluation. J Am Anim Hosp Assoc 18: $729-736$

ELLISON GW 1989: Wound healing in the gastrointestinal tract. Semin Vet Med Surg Small Anim 4: 287-293

GÖPFERTOVÁ D, HLADÍKOVÁ M, ŠEJDA J, HROBOŇ P 1999: Epidemiologie. $1^{\text {st }}$ ed. Vydavatelství Univerzity. Palackého v Olomouci, pp. 442-443

HEDLUND CS 2002: Surgery of the small intestine: general principles and techniques. In: FOSSUM TW (Ed): Small Animal Surgery. $2^{\text {nd }}$ ed. Mosby, St. Louis, pp. 369-398

IRVIN TT, GOLIGHER JC 1973: Aetiology of disruption of intestinal anastomoses. Br J Surg 60: 461-464

MAIR TS, SMITH LJ 2005: Survival and complication rates in 300 horses undergoing surgical treatment of colic. Part 3: Long-term complications and survival. Equine Vet J 37: 310-314

McLACHLIN AD, DENTON WD 1973: Omental protection of intestinal anastomoses. Am J Surg 125: 134-140

MENZIES D, ELLIS H 1990: Intestinal obstruction form adhesion - how big is the problem? Ann R Coll Surg Engl 72: 60-63

MONK BJ, BERMAN ML, MONTZ FJ 1994: Adhesions after extensive gynaecologic surgery: Clinical significance, etiology, and prevention. Am J Obstet Gynecol 170: 1396-1403

O’KELLY TJ, KRUKOWSKI ZH 1998: Intestinal anastomosis. Surgery 17: 197-200

PLÁNKA L, TƯMA J, RAK V, GÁL P 2006: Výsledky elektivní laparoskopické apendektomie u nejasných bolestí v pravém hypogastriu. (In Czech, Results of the elective laparoscopic appedectomy in unexplained pains in the right hypogastrium). Rozhl Chir 85: 343-346

RICHARDSON DC 1981: Intestinal surgery: A review. Compend Contin Educ Pract Vet 3: 259-270

SEMEVOLOS SA, DUCHARME NG, HACKETT RP 2002: Clinical assessment and outcome of three techniques for jejunal resection and anastomosis in horses: 59 cases (1989-2000). J Am Vet Med Assoc 220: 215-218

SMITH BA, HOSGOOD G, HEDLUND CS 1995: Omental pedicle used to manage a large dorsal wound in a dog. J Small Anim Pract 36: 267-270 
Plate IV

Crha M. et al.: Two Techniques ... pp. 263-267

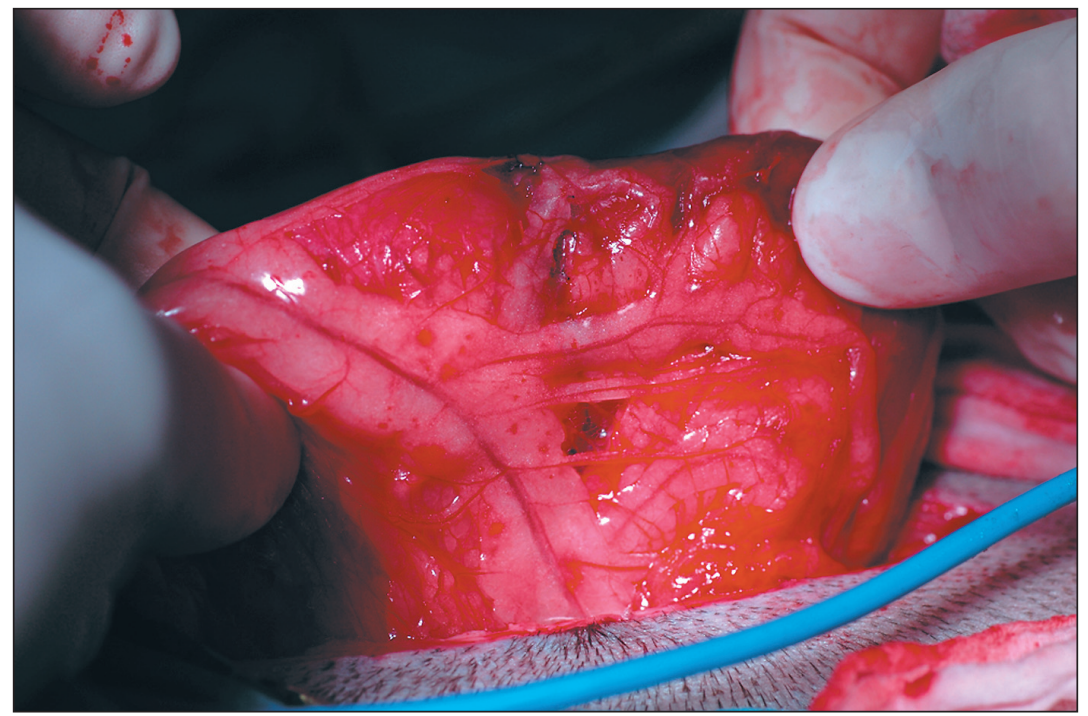

Fig. 1. Omentalisation of intestinal anastomosis after resection of a part of the jejunum. The assistant's fingers hold the intestinal loop covered with the omentum

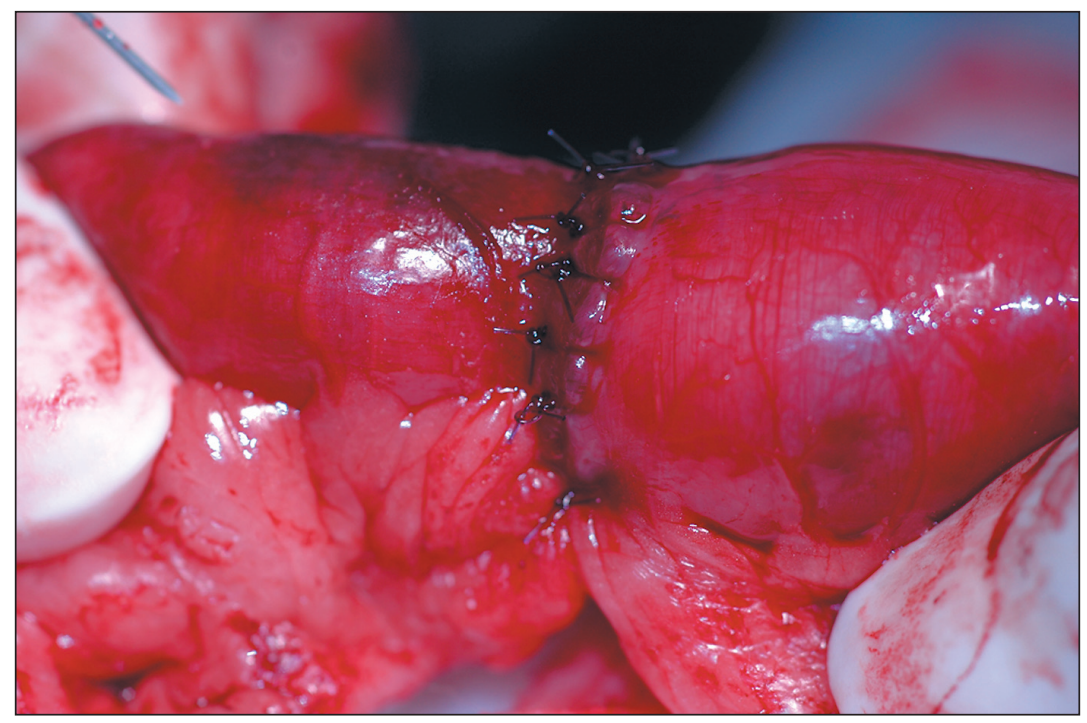

Fig. 2. Approximation "end-to-end" anastomosis of the jejunum. Checking for leakage between sutures of enteric anastomosis by intestinal loop dilation with saline 


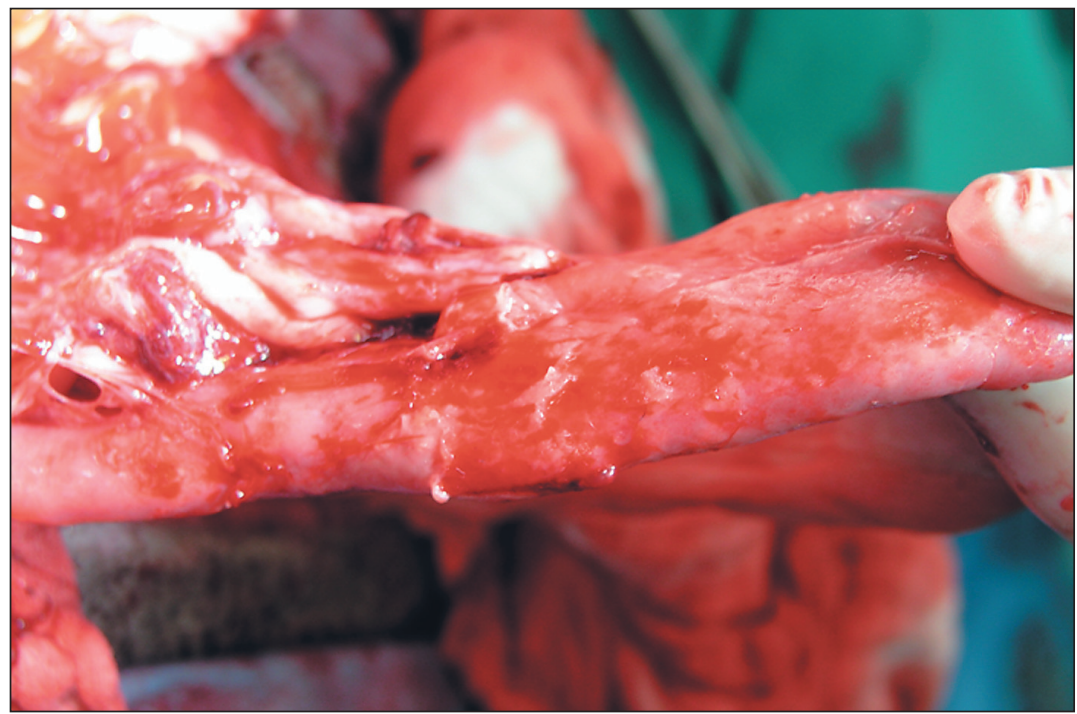

Fig. 3. Focal adhesion of the omentum to the jejunal wall at the site of dehiscence of the surgical incision of the intestinal wall 